\title{
DEEP ECONOMIC INTEGRATION AND STATE CAPACITY: A MECHANISM FOR AVOIDING THE MIDDLE-INCOME TRAP?
}

László Bruszt and Nauro F. Campos

NO. 547

June 2018
ADB ECONOMICS WORKING PAPER SERIES 


\section{Deep Economic Integration and State Capacity: A Mechanism for Avoiding the Middle-Income Trap?}

László Bruszt and Nauro F. Campos

No. 547 | June 2018
László Bruszt (laszlo.bruszt@eui.eu) is a Professor at the Department of Political Sciences, Central European University. Nauro F. Campos

(nauro.campos@brunel.ac.uk) is a Professor of Economics at Brunel University London and a Research Professor at ETH-Zürich.

This paper has been prepared as background material for the Asian Development Outlook 2017 theme chapter on Transcending the Middle-Income Challenge. We would like to thank Erick Berglof, Gergö Medve-Bálint, Joergen Moeller, Yasuyuki Sawada, Donghyun Park, and seminar participants at the London School of Economics for valuable comments and suggestions to a previous version. Another version of the paper was presented at the 2017 American Economic Association Conference. Ludvig Lundstedt provided superb research assistance. 
(C) 2018 Asian Development Bank

6 ADB Avenue, Mandaluyong City, 1550 Metro Manila, Philippines

Tel +632632 4444; Fax +6326362444

www.adb.org

Some rights reserved. Published in 2018.

ISSN 2313-6537 (print), 2313-6545 (electronic)

Publication Stock No. WPS189408-2

DOI: http://dx.doi.org/10.22617/WPS189408-2

The views expressed in this publication are those of the authors and do not necessarily reflect the views and policies of the Asian Development Bank (ADB) or its Board of Governors or the governments they represent.

ADB does not guarantee the accuracy of the data included in this publication and accepts no responsibility for any consequence of their use. The mention of specific companies or products of manufacturers does not imply that they are endorsed or recommended by ADB in preference to others of a similar nature that are not mentioned.

By making any designation of or reference to a particular territory or geographic area, or by using the term "country" in this document, $A D B$ does not intend to make any judgments as to the legal or other status of any territory or area.

This work is available under the Creative Commons Attribution 3.0 IGO license (CC BY 3.0 IGO)

https://creativecommons.org/licenses/by/3.0/igo/. By using the content of this publication, you agree to be bound by the terms of this license. For attribution, translations, adaptations, and permissions, please read the provisions and terms of use at https://www.adb.org/terms-use\#openaccess.

This CC license does not apply to non-ADB copyright materials in this publication. If the material is attributed to another source, please contact the copyright owner or publisher of that source for permission to reproduce it. $\mathrm{ADB}$ cannot be held liable for any claims that arise as a result of your use of the material.

Please contact pubsmarketing@adb.org if you have questions or comments with respect to content, or if you wish to obtain copyright permission for your intended use that does not fall within these terms, or for permission to use the ADB logo.

Notes:

In this publication, “\$” refers to United States dollars.

Corrigenda to ADB publications may be found at http://www.adb.org/publications/corrigenda. 


\section{CONTENTS}

TABLES AND FIGURES

iv

ABSTRACT $v$ V

$\begin{array}{ll}\text { I. INTRODUCTION } & 1\end{array}$

II. CONCEPTUAL FRAMEWORK 3

A. Judiciary (Montesquieu) 4

B. $\quad$ State Bureaucracy (Weber) 5

C. Start with the Demand Side for Institutional Change: Competition Policy (Smith) 5

D. $\quad$ Change the Supply Side of Institutional Change First (Montesquieu and Weber) 6

E. Induction of Virtuous Circles (Montesquieu or Weber, and Smith) 6

III. MEASUREMENT

A. Judiciary (Montesquieu) 8

B. $\quad$ State Bureaucracy (Weber) 10

C. $\quad$ Competition Policy (Smith) 11

IV. METHODOLOGICAL ISSUES

V. EMPIRICALRESULTS

VI. IMPLICATIONS FOR MIDDLE-INCOME ASIA

$\begin{array}{ll}\text { VII. CONCLUSIONS } & 17\end{array}$

$\begin{array}{ll}\text { REFERENCES } & 19\end{array}$ 


\section{TABLES AND FIGURES}

\section{TABLES}

$1 \quad$ Measuring Progress to European Union Institutional Requirements

2 Determinants of Administrative Capacity: A Comparison of Fixed Effects, System

Generalized Method of Moments, and Ordered Probit Estimators

\section{FIGURES}

1 Institutional Conditions of Joining the Single European Market

2 Diagrammatic Representation of Main Results 


\begin{abstract}
Exiting the middle-income trap entails costly improvements in state capacity. That deep economic integration induces powerful actors to support increasing state capacities remain underresearched. Here we ask: Under what conditions can deep economic integration yield increases in state capacity? We measure institutional change in 17 European former communist countries exposed to similar challenges of deep integration (European Union membership candidates), and find large variation in the evolution of their state capacities. To understand this variation, we put forward a conceptual framework and supporting hypotheses. From testing these, we empirically identify key relationships and specific reform implementation sequences. Our main result is the centrality of an intricate relationship between bureaucratic independence and judiciary capacity as a main driver of institutional change. Change in these two institutional fields, we find, is a precondition for increasing internal and external competition, which are key factors for successfully escaping the middle-income trap.
\end{abstract}

Keywords: institutions, middle-income trap, state capacity

JEL codes: D85, H41, O17, O18 


\section{INTRODUCTION}

Getting out of middle-income trap entails changes in state capacities that might be hard to attain in many countries around the world where powerful insiders and incumbents have high stakes in maintaining the status quo. It remains underappreciated that deep economic integration, which goes beyond free trade agreements, can induce powerful actors to support increasing state capacity. In this paper, we ask: Under what conditions can deep economic integration yield increases in state capacity?

There are multiple ways integration takes place. One simple dichotomy contrasts shallow with deep, with the former restricted to trade liberalization and the latter encompassing the creation of the conditions for freer movement of capital and services on the basis of joint economic and political integration. ${ }^{2}$ Free trade area agreements are a form of shallow integration, while custom unions with encompassing regulatory harmonization and the construction of common institutions are a form of deep integration. ${ }^{3}$

A robust coalition of domestic and external actors might have common stakes in supporting encompassing institutional change necessary for participation in deep integration. Domestic economic actors, who could gain from accessing much larger markets, might be strong supporters of upgrading state institutions. Domestic state elites might be enthusiastic supporters of state reform in the expectation of increases in tax revenues, and lesser pressure on public expenditures due to the weakening of domestic rent-seeking alliances exposed to external competition. Powerful external private actors might have strong interests in fighting for a "race to the top" at the level of state institutions that could guarantee even-handed enforcement of the rules of the integrated markets (Vogel and Kagan 2002). Similarly, external public actors might have strong incentives to press for domestic institutional change necessary to defend the integrity of the common markets (Bruszt and Langbein 2015).

In this paper, we argue that deep integration can provide substantial impetus for countries to escape the middle-income trap. Our argument builds upon the Schumpeterian perspective to growth and development that stresses the key role played by competition and innovation in escaping the middle-income trap (Aghion, Akcigit, and Howitt 2013). We take from this literature that changing the capacities of states is the precondition of changing developmental paths. The key state capacity mentioned in that literature is the capacity to increase external and internal competitions. Given the potentially strong resistance to such a change, there is a need to increase the autonomy of the bureaucracy, and increase its capacity to provide public goods.

Increasing state capacity might set in motion virtuous circles that could help countries to get out of the middle-income trap. The professionalization and depoliticization of civil service might increase the predictability of the state, and allow for the coming of more sophisticated foreign direct investment that could alter, in turn, the demand side for a more capable state. The increased efficiency and autonomy of the judiciary could yield more stable property rights, and it could provide room for

\footnotetext{
State capacity has always enjoyed a stable centrality in the political science scholarship. Key references are Evans, Rueschemeyer, and Skocpol. (1985); Geddes (1994); and Weiss (1998). Economists working on the issue are Acemoglu, García-Jimeno, and Robinson (2015); Besley and Persson (2009, 2011); and Dincecco and Katz (2016). Savoia and Sen (2015) provide an excellent survey.

See, among others, Baldwin (2012), Beeson (2014), and Hoekman (2016).

3 Tinbergen famously contrasted positive and negative integrations. Positive refers to the creation of common institutions, and negative to the destruction of tariff walls. Balassa suggests there are various stages of integration and places customs unions one step above free trade areas.
} 
innovation and more complex investments. At least as importantly, a depoliticized professional bureaucracy and an independent and efficient judiciary can increase the efficiency of the implementation of the rules of competition, and force firms this way to move from rent-based profit strategies to innovation and technological upgrading.

In this paper, we focus on the question: Under what conditions will deep integration yield changes in these elementary state capacities? We are using an ideal sample and much-improved measures to test various propositions about the right sequencing of institutional change that could yield the coming about of state capacities stressed in the Schumpeterian perspective. In our sample, out of 18 countries, 9 escaped the middle-income trap, ${ }^{4} 6$ has experienced transitions from lower to upper-middle income..$^{5}$ The three cases for which we observe no transitions are: Kosovo (lower), and Montenegro and Serbia (upper-middle income).

Using the annual monitoring reports produced by expert teams for the European Commission, we quantify changes over time in state capacity in these 17 Central and Eastern European (CEE) countries (candidates for European Union [EU] membership). ${ }^{6}$ We find large variation in the evolution of these capabilities. In exchange for access to a 500 million large market, these countries were exposed to the same set of requirements in domestic institutional change encompassing more than 30 policy fields ranging from environmental regulation to transportation. More importantly, the CEE countries were supposed to make considerable upgrading in three key groups of state institutions that determine the possible scope of change in all the other institutional arenas: the judiciary, the bureaucracy, and competition policy. Eleven of these countries have already joined the EU; another six are still in the process of meeting the requirements of membership. ${ }^{7}$ In our research, we found large variation, both in the sequencing and the outcomes of domestic institutional change. While several of the countries have succeeded to achieve considerable change across a wide range of state institutions, some have made only modest changes in few institutional arenas. Clearly, the effects of deep integration on domestic change vary with some sequences of institutional change being more effective than others. Our task in this paper is to explore the question: What could be the best sequencing of the changes in institutions and policies that yield progress in economic integration and simultaneous improvements in state capacities?

We first put together a conceptual framework to guide our empirical analysis that features key ideas from political economy, the separation of powers, and the benefits of enforcing economic competition. The three main strands that support our framework are ideas from Baron de Montesquieu (1777), Max Weber (1968), and Adam Smith (1776) as this paper attempts to identify empirically key relationships between institutional and regulatory reforms in three abovementioned core areas; namely, the judiciary, bureaucracy, and competition policy (or antitrust policy, as it is more often called in the United States). All three of these classics have provided strong arguments as to why their preferred institution was necessary for the extension of markets, and their ideas provide a robust

4 This uses the latest World Bank classification and turning points: Croatia in 2008, Czech Republic 2006, Estonia 2006, Hungary 2007, Latvia 2012, Lithuania 2012, Poland 2009, Slovakia 2007, and Slovenia in 1997.

5 Albania in 2011, Bosnia 2008, Bulgaria 2006, Macedonia 2007, Romania 2005, and Turkey 2004.

6 For further details on the data set see http://userpage.fu-berlin.de/kfgeu/maxcap/system/files/maxcap_wp_25.pdf (Bruszt and Lundstedt 2016).

7 Progress reports in our sample: Albania 2005-2013, Bosnia 2005-2013, Bulgaria 1997-2006, Croatia 2005-2013, Czech Republic 1997-2003, Estonia 1997-2003, Hungary 1997-2003, Kosovo 2005-2013, Latvia 1997-2003, Lithuania 19972003, Macedonia 2007-2013, Montenegro 2007-2013, Poland 1997-2003, Romania 1997-2006, Serbia 2005-2013, Slovakia 1997-2003, Slovenia 1997-2003, and Turkey 1998-2013. 
basis for exploring various present-day theories about the right sequencing of change among these institutions.

Based on our exploration of this data set, we find a small number of key implementation sequences, chief among them is the independence of the bureaucracy, which seems driven by judiciary capacity, competition policy, and administrative capacity. Our results help to identify which policy implementation sequences were the most important, they highlight the central and, indeed, intricate relationship between bureaucratic independence and judiciary capacity that seem to play the role of the main driver of institutional convergence.

\section{CONCEPTUAL FRAMEWORK}

Market integration, the removal of national discriminations among producers, goods, services, and people in the realm of the economy, has progressed very slowly across the globe. Most of the attempts at furthering market integration stop at a very shallow level, involving at most a free trade agreement with limited common regulations in very few areas (Balassa 1961). The integration by the EU of the CEE economies from this perspective seems to be a unique experience as it has involved the rapid abolition of all tariffs and the transfer of around 80,000 pages of common regulations covering more than 30 policy fields. Besides the restructuring of key economic institutions, deep integration extended to the remaking of the two central institutional arenas of the state: the judiciary and the state bureaucracy.

The stress on state reform by the EU was strongly linked to a key dilemma of deep economic integration. The creation and the extension of a common market presuppose the capacity of all members to play by the common rules. Implementation of these rules might be costly and, at least as importantly, it might require considerable administrative and judicial capacities that could conceivably be in short supply in the less developed countries (Bruszt and McDermott 2014). An eventual largescale noncompliance in the countries with weaker states could undermine the integrity of the regional market. Such vulnerability of the regional integration grows with the number of policy areas that are included in institutional harmonization and with the potential importance of the lesser developed economies as trading partners or production sites.

The simultaneous initiation of accession negotiations with, first 10 and then another 7, CEE countries represented exactly such a challenge. Key EU actors perceived the Eastern enlargement as a factor potentially endangering the results of the previous waves of economic integration (European Commission 1997).

In our research, we found that, even after the EU has invested 7-10 years' effort in furthering institutional upgrading in the CEE countries, the outcomes are highly diverging across and within these countries.

How were these paths of institutional change interlinked? Was there a right sequencing of change within and across the key institutional areas that has allowed for progress in transforming key state institutions? What role did the sequencing of institutional change play in the dramatic divergence of outcomes?

We seek theoretical guidance to these questions in the classics of political thought. Our background assumptions rely on the ideas of those political scientists, economists, and sociologists who have stressed the dynamics of self-reinforcing or positive feedback processes instead of timeless 
relations among diverse variables (Pierson 2000, Tilly 1984). We look at institutional transformation as a complex set of interlinked changes in multiple arenas, whereby the timing of a change within a sequence affects how change happens and also what effects it has on change in other institutional arenas. In this approach, early events can trigger self-perpetuating processes or they can set in motion a backlash that hinders further institutional change (Stinchcombe 1968, Pierson 2000).

\section{A. Judiciary (Montesquieu)}

The reforming of the judiciary was one of the key institutional arenas of state reform that the EU deemed equally crucial for the upholding of democratic political rights and economic freedoms.

From a theoretical perspective, the reform of judiciary had to create a key institutional condition of credibly committing the aspiring member states to sanction the rules of the EU. Also, putting in place an independent judiciary with the capacity to efficiently and evenhandedly enforce economic freedoms and the rules of the common market could, in principle, set in motion at least two interlinked mechanisms that would reinforce institutional change in other institutional arenas. The stabilization of the expectation of economic players that they can safely invest and contract, because the judiciary predictably enforces their rights independently of their differences in economic and/or political power, can increase the number and alter the composition of economic players. This way, judiciary reform can change the balance of power on the demand side of state reform. The increasing returns of judiciary autonomy and efficiency can also alter the incentives of state incumbents to supply improved institutional conditions in more specific policy areas in order to further improve the revenue basis of the state.

But what are the institutional conditions of judiciary independence? In defining these conditions, we can rely on the ideas of Montesquieu. The institutional sources of judiciary independence have to do with the separation of powers. The judiciary should be independent of both the legislature and the executive, and should restrict itself to applying the rules of the common market to particular cases in a fixed, transparent, and consistent manner.

In formulating our first hypothesis, we rely on the late 18th century upgrading of the ideas of Montesquieu by the founding fathers of American Constitution (Manin 1994). Their starting point was the same as that of Montesquieu; key to the stabilization of the common market of the 13 North American states lies with the creation of independent judiciary. But, learning from the weaknesses of previous constitutional solutions, the American founding fathers were not satisfied with the notional separation of the different branches of the state. They thought that solely the constitutional declaration of the independence of judiciary would not do. Among the three branches of governments there was a hierarchy in the degree of legitimacy. Branches of government with stronger legitimacy, the executive and the legislative, they argued, could encroach on the autonomy of the branch with weaker legitimacy, like the judiciary. Their conclusion, therefore, was that the mechanical separation of powers will, on their own, not do and each branch should be empowered with the necessary powers to defend its boundaries from encroachment. In the case of the judiciary, these were the powers given to the judiciary to oversee the constitutionality of the legislative and the executive.

Based on the above discussion we can formulate the following hypothesis:

H1: The sooner there will be progress in terms of establishing an independent constitutional court, the faster can countries create an independent judiciary. 


\section{B. State Bureaucracy (Weber)}

The other institutional arena that was seen by the EU as crucial for integrating the CEE economies was public administration. The concerns of the EU in this field were similar to the one described above with reference to the judiciary. Only a depoliticized, professional bureaucracy can efficiently implement, administer, and enforce the rules of the common market. The expected self-reinforcing benefits of state reforms were the same as in the case of judiciary (European Commission 1997).

But, what could be the right sequence of reforms within the public administration? What should come first, the professionalization of the bureaucracy implying the meritocratic selection and promotion together with employment protection, or the establishment of the legal defences from politicization of the state bureaucracy?

In formulating this hypothesis, we rely on the work of Max Weber (1968) who was the first to stress the intimate relationship between the spread of large-scale capitalist enterprise and modern bureaucratic state. He also stressed the strong association between the emergence of rational law and well-functioning bureaucracy.

Evans (1995) argued that the key factor explaining variation in state capacities was the corporate coherence of the autonomous state: the existence of defences for the civil service from short-term political or economic interests. Highly selective meritocratic recruitment and promotion and, in general professionalization of the bureaucracy were the key to create a cohesive bureaucracy with an esprit de corps, with its own professional criteria of success. Such a cohesive bureaucracy had, Evans argued, stronger defences against repoliticizing and against capture by private interests. Based on the above discussion we can formulate the following hypothesis:

H2: The sooner there will be progress in the implementation of reforms that strengthen the professionalization of the civil service, the faster will be progress in the implementation of measures that increase the independence of state bureaucracy.

\section{Start with the Demand Side for Institutional Change: Competition Policy (Smith)}

We have discussed above two propositions about sequences of change within specific institutional arenas. We continue with three further propositions that are linked to the question about the right sequencing of change across these institutional arenas. According to the first, institutional change should start with the institutions that could induce and maintain competition; according to the second approach, change should start with the reform of state institutions. Finally, according to the third approach, a critical mass of change in both institutional arenas is the way to start.

The underlying idea is that the major hindrance before institutional change is in the wrong constellation of economic interests that hold the state captive in a bad status quo. The key is the speed of changes (Åslund, Boone, and Johnson 1996, 217), not allowing time to react and resisting the implementation of the right measures.

Translated to the level of institutional change, from this perspective the implementation of the institutional conditions of competition policy and the free movement of goods and capital are the ways to start (Motta 2004). The implementation of EU conform rules of competition allows new entrants to the domestic market; they will weaken the powers of the dominating economic groups and alter the 
demand side for implementing the necessary steps for integration. The state will be liberated to introduce the reform of the state bureaucracy and the judiciary.

We here call this the Adam Smith channel. In the Wealth of the Nations, Adam Smith highlighted the dangers of the presence of monopolies on the state:

"The interest of the dealer, however, in any particular branch of trade or manufacture, is always in some respects different from, and even opposite to, that of the public. To widen the market and to narrow the competition is always the interest of the dealers." (Smith 1776, 219-20)

Based on the above discussion, we formulate the following hypothesis:

H3: The sooner there will be progress in implementing EU conform institutional change in the field of competition policy and free movement of goods, the faster there will be progress in civil service reform and the reform of the judiciary.

\section{Change the Supply Side of Institutional Change First (Montesquieu and Weber)}

A different view from the above is to have, as a first step in the complex processes of economic transformation, to build up the defenses of the state. Opening up the markets without first strengthening general state capacities could get to stalemate at the best, or it could lead to state capture at the worst (e.g., Dewatripont and Roland 1992, 1995). The new entrants might not change the nature of the demand side for state reform; they might just exploit the weaknesses of the state. The implication of these arguments is that the better way is to start with the measures of state strengthening suggested on the basis of Montesquieu and Weber, and create first the institutional conditions of functioning judiciary and bureaucracy.

Based on this discussion, we can formulate the following hypothesis that is the opposite of the preceding one:

H4: The sooner there will be progress in implementing EU conform civil service reform and the reform of the judiciary, the faster will be progress in the field of competition and free movement of goods.

Reforms creating a judiciary endowed with institutional guarantees of independence and a depoliticized civil service are expected to bring about two veto points within the state, and increase its capacity to resist capture. Such a state then is expected to have the capacity to induce positive feedback loops by undertaking sustainable institutional changes in the more specific regulatory fields, including those that could alter the demand side of integration.

\section{E. Induction of Virtuous Circles (Montesquieu or Weber, and Smith)}

Based on the critique of the above two general approaches, one can generate a third hypothesis. One could argue, first, that reforms might not generate enough defences for the autonomy of the state without some change in the demand side of the reform. Even multiple veto points within the state, meaning the existence of the institutional guarantees of the independence of the judiciary and the bureaucracy, might not provide a sufficient defence for the state if all the veto points could be controlled by status quo-oriented economic and political groups (Stasavage 2002). It is hard to lock in externally supported state reforms if the factors that have created the intertwining between public and 
private actors prior to the reform are not broken with the help of new proreform alliances in the economy.

On the other hand, except for the sweeping transformation of the demand side in the economy, the emerging alliances for institutional change need at least one defense: at least one veto point within the state in order to lock in reform. Change in the demand side for reform, on its own, might not generate sufficient enough support for institutional change in the economy, if there is not some simultaneous progress in reform within at least one branch of the state.

To set institutional change in motion, one should expect a combination of supply and demandside reforms to generate progress in deep integration.

H5: The sooner there will be simultaneous change in regulatory institutions responsible for competition and the free movement of goods on the one hand, and in some aspects of implementing EU conform civil service reform or the reform of the judiciary on the other hand, the more likely it is to have cumulative progress in other general state institutions.

Based on the above discussion, we can now summarize the key institutional requirements of deep integration as they were seen from Brussels. Notice that Figure 1 represents only the core of EUmandated institutional changes in the applicant countries. A fuller picture would include the institutional requirements in more than 30 specific policy fields from environmental regulation to food safety regulation. Note also that Figure 1 does not represent any EU expectations about sequencing of change. During the first wave of Eastern enlargement, Brussels left it to the aspiring member state to choose their own sequencing strategy.

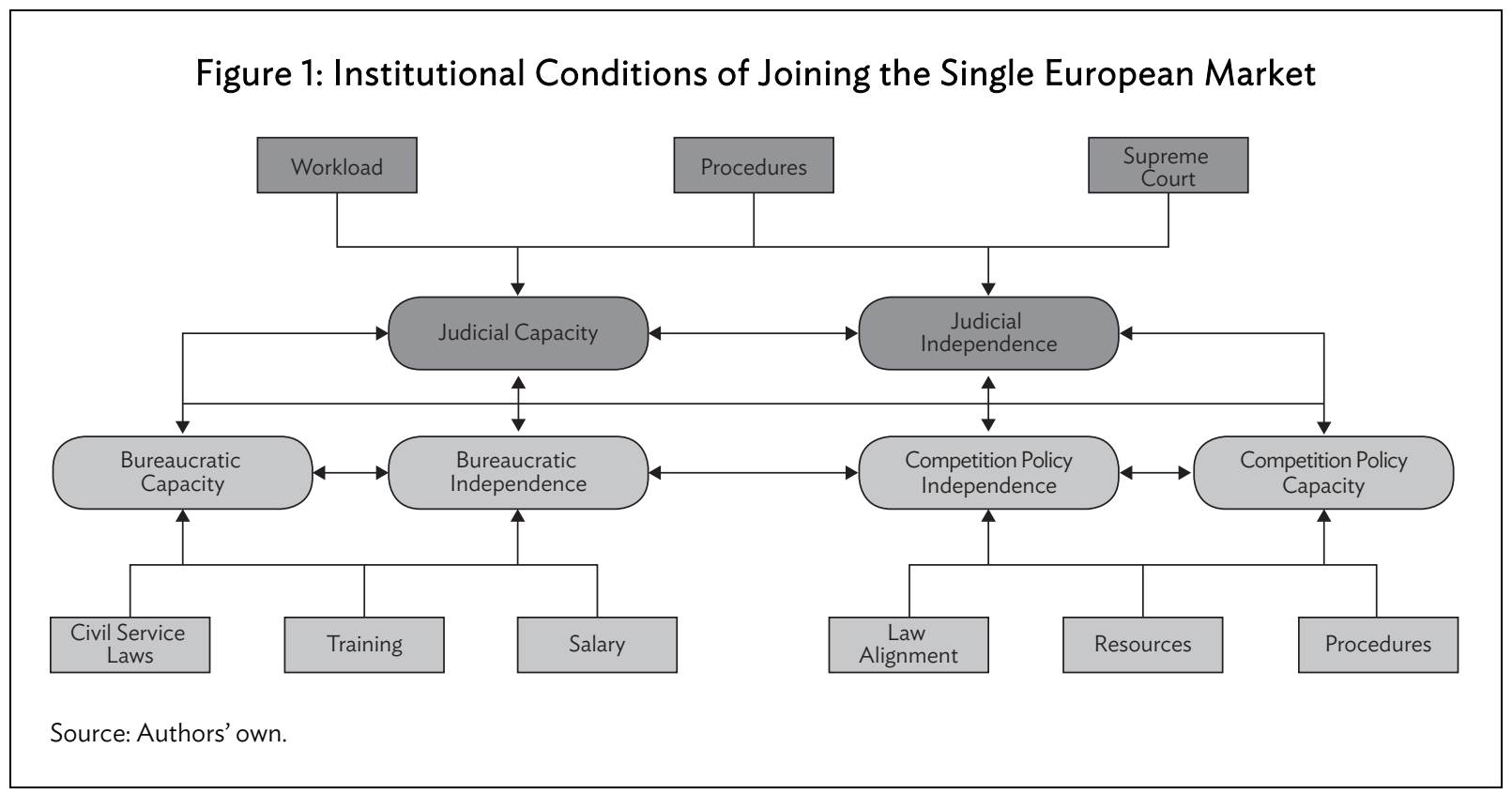




\section{MEASUREMENT}

In this section we provide description of the data used in our analysis. We have also prepared a detailed codebook for those interested in further details on the data set that is available online. ${ }^{8}$ This paper focuses on three key regulatory areas; namely, the judiciary, public administration (the bureaucracy), and competition policy. For each one of these areas, we quantify the various aspects that the European Commission judged to be crucial. It is important to notice that the European Commission never differentiates between inputs and outcomes in the progress reports. It evaluates each of the aspects individually without taking into account the potential relationships among them. Based on our understanding of each regulatory area, we decided which variables are deemed inputs and which are deemed to be outcomes. For each of the three areas, we are able to identify two main outcomes (capacity and independence, which are similar across the three areas), as well as the various inputs into the delivery of these outcomes (which are not similar across the three areas). For the data collection, a codebook has been prepared that aimed to capture, wherever possible, the institutional dimensions discussed above. ${ }^{9}$ The objective of this section is to discuss how each of these inputs and outcomes of the three regulatory areas was operationalized and measured.

\section{A. Judiciary (Montesquieu)}

Judiciary outcomes are measured in terms of both judiciary capacity and judiciary independence. Capacity refers to access to necessary resources, expertise, and training. EU norms establish basic parameters for the functioning of the judiciary. Conformity with these norms basically speaks to the workload and to delays in the workings of the judicial system. The expert teams responsible for the progress reports evaluate judiciary capacity, and our coding of their assessment range from 1 to 4 as detailed in Table 1. Judicial independence refers to independence in terms of appointment, promotion, and remuneration. Thus, corruption of the judicial system (which also affects the independence of the judiciary) is not dealt with in this dimension, but in the input legal procedural dimension discussed below.

Regarding the judiciary, we focus on three main inputs that we theorize can potentially contribute to the "production" of capacity and of independence as defined above. One regards the constitutional dimension (existence and strength of a supreme court), the second centers on the workload ("behavioral dimension" in the codebook), and the third focuses on the "legal procedures dimension" of the judicial system. ${ }^{10}$ It is also important to note that, when corruption happens to be an issue identified with respect to the judiciary, it is always reflected in the coding of this last particular item." $^{11}$

Let us now turn to each of the three inputs for the Montesquielian channel. The constitutional dimension of the judiciary centers on the existence and functioning of the supreme (or constitutional) court. Constitutional control is sometimes referred to as the supreme court's ability to safeguard citizens' rights. The important features of a supreme court endowed with the necessary powers are (i)

8 See http://userpage.fuberlin.de/kfgeu/maxcap/system/files/maxcap_wp_25.pdf.

9 For further details on the data set see http://userpage.fu-berlin.de/kfgeu/maxcap/system/files/maxcap_wp_25.pdf (Bruszt and Lundstedt 2016).

10 This dimension covers three different aspects: (i) access to courts (e.g., the right to appeal); (ii) the court procedure (e.g., legal certainty, which in turn includes a unified interpretation of the law by the courts, the requirement of justification for judicial decisions, and an evenly handled procedure); and (iii) the enforcement of judicial decisions.

11 If corruption is mentioned as a problem for the judiciary in a progress report, the report should be coded 1 or 2 , depending on if efforts to remedy the problem with corruption have been taken. 
the possibility of citizens to refer complaints to the court, and (ii) the parliament and/or the executive is not able to overturn decisions made by the supreme court.

The workload is key to the behavioral dimension of judiciary reform. EU norms establish basic parameters for the functioning of the judiciary. Conformity with these norms speaks to workload and delays (Table 1).

The last input into judiciary capacity and independence refers to the existence and effectiveness of legal procedures. This dimension reflects ease of access to courts and the expected certainty of judicial decisions, both in terms of their content and of their enforcement. As EU norms are quite developed in this regard, the scale used reflects the degree of conformity.

Table 1: Measuring Progress to European Union Institutional Requirements

\begin{tabular}{|c|c|c|c|c|}
\hline & Grade 1 & Grade 2 & Grade 3 & Grade 4 \\
\hline Judiciary capacity & Severe deficiencies & $\begin{array}{l}\text { Unsatisfactory } \\
\text { convergence to } \\
\text { EU norms }\end{array}$ & $\begin{array}{l}\text { Some more efforts } \\
\text { are necessary to } \\
\text { comply with EU } \\
\text { requirements. }\end{array}$ & $\begin{array}{l}\text { Comparable with } \\
\text { other EU member } \\
\text { states }\end{array}$ \\
\hline $\begin{array}{l}\text { Judicial } \\
\text { independence }\end{array}$ & $\begin{array}{l}\text { Severe political } \\
\text { pressure on the } \\
\text { courts }\end{array}$ & $\begin{array}{l}\text { Unsatisfactory } \\
\text { convergence to } \\
\text { EU norms }\end{array}$ & $\begin{array}{l}\text { Minor strengthening } \\
\text { of need to comply } \\
\text { with EU requirements }\end{array}$ & $\begin{array}{l}\text { Comparable with } \\
\text { other EU member } \\
\text { states }\end{array}$ \\
\hline $\begin{array}{l}\text { Existence and } \\
\text { functioning of } \\
\text { supreme court }\end{array}$ & $\begin{array}{l}\text { No supreme court or } \\
\text { severe deficiencies in } \\
\text { its power }\end{array}$ & $\begin{array}{l}\text { Unsatisfactory } \\
\text { convergence to } \\
\text { EU norms }\end{array}$ & $\begin{array}{l}\text { Generally satisfactory } \\
\text { powers, but further } \\
\text { strengthening is } \\
\text { needed }\end{array}$ & $\begin{array}{l}\text { Fully endowed with } \\
\text { powers to monitor } \\
\text { and exercise } \\
\text { constitutional control }\end{array}$ \\
\hline $\begin{array}{l}\text { Workload of the } \\
\text { judiciary }\end{array}$ & $\begin{array}{l}\text { Courts are severely } \\
\text { overloaded, } \\
\text { unjustified delays }\end{array}$ & $\begin{array}{l}\text { Unsatisfactory } \\
\text { convergence }\end{array}$ & $\begin{array}{l}\text { Workload of the } \\
\text { courts close to } \\
\text { satisfactory, but } \\
\text { minor backlogs }\end{array}$ & $\begin{array}{l}\text { Workload of the } \\
\text { courts satisfactory }\end{array}$ \\
\hline Legal procedures & $\begin{array}{l}\text { Severe deficiencies in } \\
\text { legal procedures }\end{array}$ & $\begin{array}{l}\text { Unsatisfactory } \\
\text { convergence }\end{array}$ & $\begin{array}{l}\text { Generally } \\
\text { satisfactory, some } \\
\text { improvements are } \\
\text { needed }\end{array}$ & Satisfactory \\
\hline $\begin{array}{l}\text { Independence of the } \\
\text { bureaucracy }\end{array}$ & Severe deficiencies & $\begin{array}{l}\text { Unsatisfactory } \\
\text { convergence }\end{array}$ & $\begin{array}{l}\text { Generally } \\
\text { satisfactory, some } \\
\text { improvements are } \\
\text { needed }\end{array}$ & $\begin{array}{l}\text { Public administration } \\
\text { fully independent }\end{array}$ \\
\hline $\begin{array}{l}\text { Administrative } \\
\text { capacity }\end{array}$ & Severe deficiencies & $\begin{array}{l}\text { Unsatisfactory } \\
\text { convergence }\end{array}$ & $\begin{array}{l}\text { Generally } \\
\text { satisfactory, some } \\
\text { improvements are } \\
\text { needed }\end{array}$ & Satisfactory \\
\hline $\begin{array}{l}\text { Extent and quality of } \\
\text { the training }\end{array}$ & Severe deficiencies & $\begin{array}{l}\text { Unsatisfactory } \\
\text { convergence }\end{array}$ & $\begin{array}{l}\text { Generally } \\
\text { satisfactory, some } \\
\text { improvements are } \\
\text { needed }\end{array}$ & Satisfactory \\
\hline $\begin{array}{l}\text { Structure of the } \\
\text { salaries of public } \\
\text { administrators }\end{array}$ & Severe deficiencies & $\begin{array}{l}\text { Unsatisfactory } \\
\text { convergence }\end{array}$ & $\begin{array}{l}\text { Generally } \\
\text { satisfactory, some } \\
\text { improvements are } \\
\text { needed }\end{array}$ & Satisfactory \\
\hline
\end{tabular}


Table 1 continued

\begin{tabular}{|c|c|c|c|c|}
\hline & Grade 1 & Grade 2 & Grade 3 & Grade 4 \\
\hline Civil service law & Severe deficiencies & $\begin{array}{l}\text { Unsatisfactory } \\
\text { convergence }\end{array}$ & $\begin{array}{l}\text { Generally } \\
\text { satisfactory, some } \\
\text { improvements are } \\
\text { needed }\end{array}$ & Satisfactory \\
\hline $\begin{array}{l}\text { Quality of the } \\
\text { enforcement of } \\
\text { antitrust and merger } \\
\text { legislation }\end{array}$ & Severe deficiencies & $\begin{array}{l}\text { Unsatisfactory } \\
\text { convergence }\end{array}$ & $\begin{array}{l}\text { Generally } \\
\text { satisfactory, some } \\
\text { improvements are } \\
\text { needed }\end{array}$ & Satisfactory \\
\hline $\begin{array}{l}\text { Independence of the } \\
\text { competition authority }\end{array}$ & Severe deficiencies & $\begin{array}{l}\text { Unsatisfactory } \\
\text { convergence }\end{array}$ & $\begin{array}{l}\text { Generally } \\
\text { satisfactory, some } \\
\text { improvements are } \\
\text { needed }\end{array}$ & Satisfactory \\
\hline $\begin{array}{l}\text { Antitrust and merger } \\
\text { legislation }\end{array}$ & Severe deficiencies & $\begin{array}{l}\text { Unsatisfactory } \\
\text { convergence }\end{array}$ & $\begin{array}{l}\text { Generally } \\
\text { satisfactory, some } \\
\text { improvements are } \\
\text { needed }\end{array}$ & Satisfactory \\
\hline Resources & Severe deficiencies & $\begin{array}{l}\text { Unsatisfactory } \\
\text { convergence }\end{array}$ & $\begin{array}{l}\text { Generally } \\
\text { satisfactory, some } \\
\text { improvements are } \\
\text { needed }\end{array}$ & Satisfactory \\
\hline $\begin{array}{l}\text { Procedural structures } \\
\text { for market } \\
\text { surveillance }\end{array}$ & Severe deficiencies & $\begin{array}{l}\text { Unsatisfactory } \\
\text { convergence }\end{array}$ & $\begin{array}{l}\text { Generally } \\
\text { satisfactory, some } \\
\text { improvements are } \\
\text { needed }\end{array}$ & Satisfactory \\
\hline
\end{tabular}

$\mathrm{EU}=$ European Union.

Source: Authors' calculations.

\section{B. State Bureaucracy (Weber)}

Let us now turn to the bureaucracy or the quality of public administration. The evaluation on the public administration is based on the European Principles of Administration elaborated by SIGMA ${ }^{12}$ and the European Commission. Here, we look at two key outcome dimensions of the quality of public administration: independence of the bureaucracy and administrative capacity.

The notion of administrative capacity in this context means that there is sufficient professionalism in the civil service, and that a coherent institutional or organizational set of administrative structures exists so that the bureaucracy has the capacity to deliver.

We consider three key inputs into this Weberian channel; namely, (i) the extent and quality of the training, and (ii) the structure of the salaries of public administrators, as well as (iii) whether the civil service law in place is appropriate and effective ("legislative dimension" in the codebook) (Table 1).

12 Support for Improvement in Governance and Management is a joint initiative of the Organisation for Economic Cooperation and Development and the EU to strengthen the foundations for improved public governance and support socioeconomic development. 


\section{Competition Policy (Smith)}

The third dimension we consider is competition policy. The national state aid authority often goes under the name of competition office, competition council, or division of competition and state aid. Some countries divide the responsibilities between several bodies while others only have one responsible authority. The authority or authorities are, in some cases, responsible for both antitrust and merger, and state aid.

We evaluate three key inputs into the Smith channel: (i) alignment of antitrust and merger legislation with EU requirements; (ii) resources available for the enforcement of antitrust and merger legislation; and (iii) procedural structures for market surveillance, with reference to free movement of goods. ${ }^{13}$ These refer to agencies responsible to the enactment, alignment, and enforcement of competition policy.

Legislation on antitrust and mergers includes legislation on competition, cartels, plus abuse of dominant market position, market concentration, and restrictive practices (Table 1). The resource input into competition policy refers to the number and quality of staff, physical resources (information and communication technology and buildings), and general financial/budgetary resources. The third input into competition policy we consider is the procedural structures for market surveillance. Procedural structures consist of the ability of the agency to operate independently, its competences, and its powers. Competences refer to the areas the national antitrust and merger authority has the competence to make decisions. The powers refer to the strength of, for example, sanctions that the national antitrust and merger authority can impose.

Outcomes from the Smith channel are also measured in terms of capacity and independence. In the case of competition policy, we define capacity as the quality of the enforcement of antitrust and merger legislation, and we define independence in terms of the freedom from interference enjoyed by the competition authority. The independence aspect of the outcomes from competition policy comes from a different chapter in our data set, and refers to the capacity to deliver market surveillance (Table 1). ${ }^{14}$

\section{METHODOLOGICAL ISSUES}

The objectives of this section are to discuss three main methodological issues and to clarify the choices we make in this paper. One issue refers to our focus on implementation sequences, another to the overall modeling strategy, and the third to the implications for estimation of the fact that most of our variables of interest are categorical.

The aim of this paper is to empirically identify the implementation sequences of changes in three key regulatory areas. We consider the following dynamic panel data model:

$$
y_{i t}=\sum_{j=1}^{p} \alpha_{j} y_{i, t-j}+x_{i t} \beta_{1}+w_{i t} \beta_{2}+v_{i}+\epsilon_{i t} \quad i=1, \ldots, N \quad t=1, \ldots, T_{i}
$$

13 In the codebook, these variables appear under competition policy and, as indicated, all refer to antitrust and merger policy.

14 While all the three inputs and the capacity outcome for competition policy can be found under the chapter 2 entry in the codebook (competition policy), the independence measure originates from chapter 7 (free movement of goods), and refers to the extent to which the required procedures to deliver market surveillance are in place. 
where $y_{i t}$ can be one of six options as it represents one of our measures of judiciary independence or capacity, bureaucracy independence or capacity, and competition policy independence or capacity. With $\alpha_{j}$ and $p$ as parameters to be estimated, $\beta_{1}$ and $\beta_{2}$ as vectors of parameters to be estimated and the panel effects $\left(v_{i}\right)$ and $\varepsilon_{i t}$ assumed to be independent for each country $i$ and across all years $t$. Importantly, $x_{i t}$ is a vector of exogenous covariates that includes variables (or inputs) within the reform area, while $w_{i t}$ is a vector of exogenous covariates that includes the remaining five reform area outcomes.

Regarding the first issue, we decided that all right-handed variables enter in 1-year lags. This choice ameliorates endogeneity concerns and, more importantly, lends itself quite naturally to a discussion of temporal implementation sequences. A finding that one reform last year is statistically associated with a change in another reform this year can be interpreted as a temporal sequence.

Given that institutions change notoriously slowly, one must account for the potential inertia that one may think characterizes the behavior of institutional changes and, hence, in all specifications, we include the lagged dependent variable in the right-hand side.

The second important methodological issue refers to the structure of the conceptual framework we put forward above. We empirically implement this framework using a two-stage scheme: first, we estimate the effects within each channel, and then we estimate the effects between channels. In the first stage, we estimate whether and how each of the two outcome measures can be explained by the three inputs, while in the second we estimate (in addition) the effects of the other two channels. For example, let us take the Weberian channel. First, we explore whether and how administrative capacity and administrative independence were explained by (1-year lagged) civil service law, by the training of public servants and by their salaries. In the second stage, we assess whether, after accounting for these inputs, there are specific effects from the other two channels. Whether administrative independence was affected by (1-year lagged) judiciary independence or by the quality of the enforcement of antitrust and merger legislation.

The third issue is how we deal with the implications for the choice of estimation method and the fact that most of our variables are categorical. There are three obvious estimator choices. One is the fixed-effects panel estimator, the main advantage of which is that it is standard. The use of country and year fixed effects would be helpful to ameliorate criticisms of omitted variable biases, which may be important. The second is the System GMM (generalized method of moments ArellanoBover/Blundell-Bond linear dynamic panel data) estimator, which, as its main advantage, handles the presence of the lagged dependent variable, and hence is a natural choice. One issue these two options do not address is that most of our variables of interest are categorical, and thus an estimator like the ordered probit would be a more satisfactory way of handling this.

We observe that the use of these three estimators delivers qualitatively similar results. Table 2 shows one example for the case of administrative capacity. Note that the key result (regarding the role of civil service law) is robust across the three estimators. Also note that measures of goodness of fit in both the fixed effects and ordered probit cases are quite satisfactory and, more importantly, that for the System GMM estimator in column 2 the $A R(1)$ and $A R(2)$ tests suggest that the instruments we use are valid and that the model is correctly specified.

The System GMM estimator is designed for situations like ours, in which we have an unbalanced panel with a "small T and large N" (for the countries that joined the EU in 2004, our data only covers 6 years), and the left-hand side variable is defined as dynamic in that it depends on its own 
past realizations (Plümper, Troeger, and Manow 2005). Moreover, the System GMM handles well right-hand side variables that are not strictly exogenous and may be correlated with past and current realizations of the error term, (country-level) unobserved heterogeneity, measurement error, and omitted variables, as well as potential heteroscedasticity and autocorrelation within or across individual units' errors. Our estimation was implemented using Stata's xtdpsys facility.

Table 2: Determinants of Administrative Capacity: A Comparison of Fixed Effects, System Generalized Method of Moments, and Ordered Probit Estimators

\begin{tabular}{lccc}
\hline & $\begin{array}{c}(1) \\
\text { Fixed Effects }\end{array}$ & $\begin{array}{c}(2) \\
\text { System GMM }\end{array}$ & $\begin{array}{c}(3) \\
\text { Ordered Probit }\end{array}$ \\
\hline One-year lag administrative capacity & $0.434^{* * *}$ & $0.741^{* * *}$ & $6.597^{* * *}$ \\
One-year lag civil service law & {$[0.0670]$} & {$[0.138]$} & {$[1.639]$} \\
One-year lag civil servant training & $0.198^{* *}$ & $0.152^{* *}$ & $0.891^{*}$ \\
& {$[0.0775]$} & {$[0.0626]$} & {$[0.537]$} \\
One-year lag civil servant salary & 0.0584 & $0.110^{* *}$ & 0.781 \\
& {$[0.0478]$} & {$[0.0486]$} & {$[0.492]$} \\
One-year lag judiciary capacity & -0.190 & $-0.244^{* *}$ & $-1.412^{*}$ \\
One-year lag judiciary independence & {$[0.128]$} & {$[0.114]$} & {$[0.724]$} \\
& -0.00754 & 0.00614 & 0.466 \\
One-year lag competition policy quality & {$[0.0798]$} & {$[0.0687]$} & {$[0.615]$} \\
& 0.117 & 0.0557 & 0.366 \\
Constant & {$[0.116]$} & {$[0.144]$} & {$[0.394]$} \\
Observations & $0.111^{* *}$ & 0.0122 & 0.626 \\
Number of countries & {$[0.0505]$} & {$[0.0426]$} & {$[0.572]$} \\
R-squared & 0.383 & 0.301 & \\
AB test AR(1) & {$[0.319]$} & {$[0.368]$} & 104 \\
AB test AR(2) & 104 & 104 & 164 \\
\hline
\end{tabular}

GMM = generalized method of moments.

Notes: ${ }^{*} p<0.1,{ }^{* *} p<0.05,{ }^{* *} p<0.01$. Robust standard errors in brackets.

Source: Authors' calculations. 


\section{EMPIRICAL RESULTS}

Here, we first focus our presentation on the set of results for the Weberian channel (public administration or bureaucracy), and then use the diagrammatic scheme presented above to put these results in overall context and contrast them with those we obtain for the judiciary and competition channels.

One first noteworthy finding is that none of the three "inputs" into bureaucratic independence enjoys support. Civil service law, salaries, or training in previous periods do not seem associated with the current level of bureaucratic independence. ${ }^{15}$ Instead, this is better explained by other outcome variables such as bureaucratic capacity, judiciary capacity, and competition policy capacity.

Now, we turn our attention to the other outcome variable in the Weberian channel. First, we examine the relative importance of its own inputs. The main findings here are quite different than those for bureaucratic independence; inputs seem to be more important than the other outcomes. Civil service law and civil servant training in the previous year show to be positively correlated (while salaries are negatively correlated) with the current level of bureaucratic quality. Another noteworthy difference is that, in this case, inertia is much stronger than for the other outcome; previous realizations of bureaucratic quality are strongly related to current levels of it, while the same cannot be said for bureaucratic independence. Last, but not least, it is important to note that we find previous levels of quality are positively related to current levels of independence, so one can argue that the effects of the three inputs on independence is indirect, that is, it takes place through capacity. This is an example of a sequence uncovered by our results; training increases capacity, which, by its turn, leads to increases in bureaucratic independence.

We repeated the same estimation exercise above for both the judiciary and competition (Montesquieu and Smith channels), but devised a more economical way to report and discuss our results than in the more standard tabular format. As a departure point, we use Figure 1 which shows all three channels, their interrelationships and all inputs we assess in each one of the three channels to construct Figure 2 which, instead of showing all links, only shows those links (represented by arrows) for which we find robust econometric support.

Starting from the Weberian channel, the first observation is that civil servant salary in the previous period does not seem to be related to either bureaucratic capacity or independence in the current period. On the other hand, training and civil service law both positively affect future bureaucratic capacity, which, by its turn, positively affects 1-year ahead bureaucratic independence. We just described referring to Figure 2 what we discussed above from System GMM estimates so it should be easier to follow from this point onward.

15 This is confirmed by the results from the $A R(1)$ and $A R(2)$ tests that suggest the model in column 1 is not correctly specified (the other columns suggest this is because it excludes the other outcome variables as the results from these tests become supportive). 


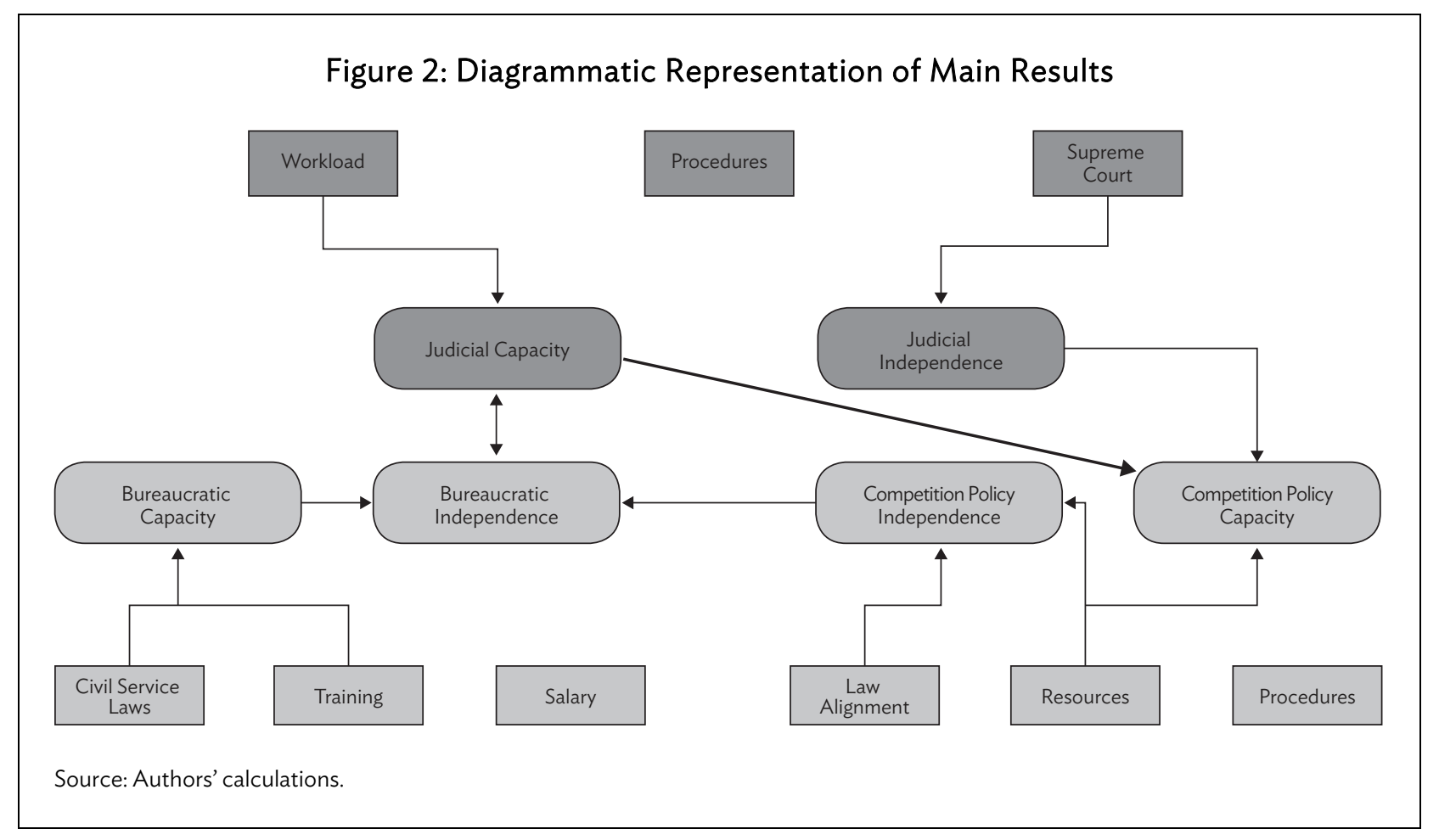

Turning to the Montesquieu channel, the most important result is the intricate, selfreinforcing, bidirectional relationship between judiciary capacity and bureaucratic independence. Judiciary capacity in the previous year is positively related to bureaucratic independence in the current year. And uniquely among our results (as can be seen in Figure 2, this is the only case in which arrows go both ways), bureaucratic independence in the last period is positively related to judiciary capacity in the current year. It can be said that this "BI-JC node" is the fulcral relationship because it is the end point for all robust sequences we uncover from our estimation results.

In summary, by using the measures and methods discussed above, we were able to document that deep integration indeed contributes to increases in key state capacities. Moreover, our analysis throws some light on how it does so. We identify various implementation sequences that depict the evolution of three important institutional areas across countries and, over time, explicitly driven by the objective of becoming a full-fledged member of the EU.

\section{IMPLICATIONS FOR MIDDLE-INCOME ASIA}

Our main finding from above is that deep economic integration is shown to play a crucial supportive role to radical and highly effective buildup of state capacities which, by its turn, contributes significantly to countries being able to escape the middle-income trap. One limitation of our results that we have been careful to highlight before is that they are limited to a very specific sample of countries (EU candidates). In this light, what are the main implications from the results above to countries outside of our sample of CEE economies, in general, and to middle-income Asian countries, in particular? We think it is important to discuss two main types of implications. The first stresses the gaps in knowledge we uncover in our study in terms of designing and carrying out evidence-based policies. The second type of implications we discuss highlights the diversity of Asian economies and takes advantage of it to propose a way of implementing, if desirable, the institutional changes we study above. 
Our results above show that, while we have progressed considerably on our conceptual understating of the role institutional change can play in helping countries develop (or escape the middle-income trap), the actual testing of these many interesting insights have been hampered by a dearth of relevant empirical measures. We use a uniquely rich data set that distinguishes between inputs and outcomes in three very different institutional arenas. The vast majority of the existing measures of institutions (i) focus solely on single outcomes (rarely discuss inputs), and (ii) avoid distinguishing different institutional areas. For example, it is extremely rare to find studies that can relate measures of bureaucracy, the judiciary, or competition policy's capacity and independence (the two outcomes we focus on here) to a set of, albeit limited, highly relevant potential inputs covering human, legal, and financial resources. Regarding granularity, the existing measures of institutions (such as the widely used Freedom House measures of democracy, political rights, and civil liberties) seldom provide a detailed breakdown across policy-relevant institutional areas (e.g., distinguishing between the judiciary and competition policy authority).

Using our much more granular institutional data, how much can it explain the more widely used measures? It is obvious that the lack of detail of existing measures is compensated by the much wider country and time coverage. Yet, how much do they overlap? What can we learn from a direct comparison of our data with the most widely used measures of institutional change?

For the present study, we have also investigated the relationship between our full set of institutional measures and the Freedom House Civil Liberties, Freedom House Political Rights and Freedom House Democracy, and Executive Constraints Measures. We obtained very different and revealing results for each of our three main institutional areas. The best results or the higher correlations were found for the case of our measures of state bureaucracy, the second best results for the judiciary, and the worse for competition policy. For state bureaucracy, we find a very solid and clear pattern: the pair-wise correlations we observe (and the supporting fixed-effects panel regressions with or without lagging the freedom house variables) point toward a much tighter relationship between the existing measures and capacity and independence of the bureaucracy (outcomes) than with the three key inputs (training, salary, and education). Moreover, we find these correlations are higher with independence of the bureaucracy (which is more of a legal or de jure dimension) than with bureaucratic capacity (which is clearly more of a de facto dimension).

The results regarding judiciary and competition are clearly not as good. For the judiciary, we find a clear pattern lacks: the pair-wise correlations with formal or de jure aspects (independence and supreme court) are substantially higher than with the rest of our variables. Notice that the relationships we uncover all carry the expected "correct signs" (for instance, more political rights are associated with more judiciary independence, supreme court strength, and judiciary capacity) but the relationships with de facto dimensions are worrisomely weak. The pair-wise correlations and panel regression results we obtain are particularly low regarding judiciary capacity and workload. The lowest correlations we observe are for competition policy. These are much lower than for bureaucracy, which in addition conveys a clear pattern of outputs versus inputs, and much lower than for the judiciary, despite the lack of overall clear patterns in this last case. Again, we observe "correct signs" (for instance, more political rights are associated with more competition policy independence and capacity), but the strength of the relationships is rather disappointing.

The consequences of this first set of findings for Asian countries are that available measures (i) mostly reflect outcomes not inputs; (ii) mostly reflect de jure and not de facto outcomes (e.g., independence but not capacity); and that (iii) this pattern seems also to be repeated in terms of broader institutional areas (with state bureaucracy being better proxied by existing measures than 
competition policy). If Asian countries are serious about maximizing and monitoring the role of the buildup of state capacities to escape the middle-income trap, then a system of indicators will need to be put in place. This is because existing measures, based on our analysis, do not seem neither sufficiently precise nor discerning to fully support evidence-based policies coordinated by the relevant multinational development agencies.

The second type of implications we discuss highlights the diversity of Asian economies and takes advantage of it to propose a way of implementing, if desirable, the institutional changes we study above. Asia is arguably the most diverse region: economically, historically, socially, and geographically (consider for instance a contrast between the People's Republic of China and Tonga). Its main five subregions are a testimony of this diversity: Central Asia, South Asia, East Asia, Southeast Asia, and the Pacific. One must consider the fact that our sample of Central European countries share a lot of its communist recent past with the countries of Central Asia which comprises Armenia, Azerbaijan, Georgia, Kazakhstan, the Kyrgyz Republic, Tajikistan, Turkmenistan, and Uzbekistan as these were all parts of the former Soviet Union. These countries similarly lack an extensive tradition with competition policy, tend to have a judiciary steeped in the socialist legal tradition, and used to have a very strong communist bureaucracy. Although, of course, the pull of EU membership is not as strong and evident as in our sample, these countries share a somewhat similar initial set of institutions, which is encouraging as it suggests institutional change is politically possible and should be monitored to maximize its effects in assisting these countries to climb the per capita income ladder.

Our results above suggest that consciously trying to build up state capacity, in particular in key areas such as the judiciary, bureaucracy, and competition that can support a range of desirable economic outcomes such as export activities and technological innovation, is a very important element in national strategies that Asian countries can use to escape the middle-income trap. From a policy point of view, this process of building up relevant state capacities can be implemented in stages across countries, and should be carefully monitored so that the lessons one learns can be applied to those countries in Asia (and elsewhere) that are still further from reaching the middle-income threshold.

\section{CONCLUSIONS}

The aim of this paper is to explore variation in the effects of deep integration on the development of state capacities from the perspective of strategies for sequencing institutional change. To do so, we made use of a new panel data set on the accession process to the EU of CEE countries.

Regarding our first hypothesis, we find it has strong support from our results. The sooner there is progress in establishing an independent constitutional court, the faster countries put in place an independent judiciary. The experience of institutional transformations in Central and Eastern Europe proved the authors of the federalist papers right. Independent constitutional courts are functional for the progress of judiciary independence suggested by Montesquieu. Our findings also support the shared expectation of Montesquieu and the authors of the federalist papers. Progress in judiciary independence increases the capacity of the state to uphold the freedoms of market, in our case, from the misuse of asymmetries in economic power. This it does by way of strengthening the enforcement of antitrust regulations.

We also find support for our second hypothesis. Early reforms that strengthen the professionalization of the civil service contribute to increasing the independence of state bureaucracy. The implementation of civil service law and progress in the training of civil servants increases 
bureaucratic capacity. The latter contributes to increasing bureaucratic independence. We did not find support for the proposition about the link between salaries and increasing bureaucratic capacity.

We find limited support for our third hypothesis. Market reforms will not further state reform on their own. On the one hand, improving the quality of competition policy has a positive effect on the autonomy of state bureaucracy. Thus, changes in the demand side of state reform can contribute to the transformation of the properties of the state in a key dimension. But the enforcement of antitrust regulation does not have the expected effect on other key aspects of the state reform; namely, the transformation of the judiciary. Just on the contrary, it is the increase in judiciary capacity that results in the increased enforcement of antitrust regulation and to the opening of the possibility for new players to enter in the market. Thus, we find no support to the notion that strengthening the institutions that can liberalize the entry of new players will further state reform on their own.

Similarly, our empirical results do not support the hypothesis that supply-side reforms, the encompassing change of the judiciary and the bureaucracy, will on their own improve the institutions regulating market competition. State reforms, we found, have a direct effect on the antitrust institutions via the increasing capacity and independence of the judiciary. The effect of increase in bureaucratic capacity and autonomy is mediated via the Montesquieu channel. In turn, progress in bureaucratic independence is reinforced by a key element of the Smith channel.

Finally, we find strong support for our fifth hypothesis. A simultaneous change in some aspects of implementing competition policy and achieving progress in civil service reform or the reform of the judiciary will most likely yield progress in other general state institutions and in regulatory institutions. We found an intricate and bidirectional relationship between judiciary capacity and bureaucratic independence. Judiciary capacity in the previous year is positively related to bureaucratic independence in the current year, and bureaucratic independence in the last period is positively related to judiciary capacity in the current year. This crucial relationship is the only case for which we find evidence of a self-reinforcing, bidirectional relationship. Further, the independence of the competition authority was shown to increase bureaucratic independence, a nucleus of the sequences of institutional reforms we uncover.

Our findings about the complex interplay between reforming the institutions of the state and the market have broader relevance for market integration attempts in middle-income Asia. Extension of transnational markets goes slowly in several parts of the world because there are no states in place that are capable of implementing sustainable institutional change. Such change presupposes increase in the capacities of the private and public actors, both to play by and live by the rules of transnational markets. External assistance or pressure to change the institutions of the market might increase the opportunities of many, or they might dramatically deteriorate the positions of large segments of the society (Bruszt and McDermott 2014). What makes the difference is whether there is a state in place that is not hostage of short-term interests, which has the capacity and autonomy to manage the developmental externalities of reforms besides enforcing the transnational rules. Shallow integration attempts that focus solely on changing market institutions, as we saw it, cannot induce self-sustaining change. Liberation of markets, we found, will not liberate the state on its own. But we also found that deep integration can increase both state capacity and state autonomy, and can set in motion selfreinforcing sequences of institutional change that can open up a path out of the middle-income trap. 


\section{REFERENCES}

Acemoglu, Daron, Camilo García-Jimeno, and James Robinson. 2015. "State Capacity and Economic Development: A Network Approach.” American Economic Review 105 (8): 2364-409.

Aghion, Philippe, Ufuk Akcigit, and Peter Howitt. 2013. "What Do We Learn from Schumpeterian Growth Theory?" NBER Working Paper No. w18824.

Åslund, Anders, Peter Boone, and Simon Johnson. 1996. "How to Stabilize: Lessons from PostCommunist Countries." Brookings Papers on Economic Activity 27 (1): 217-314.

Balassa, Bela. 1961. “Towards a Theory of Economic Integration.” Kyklos 14 (1): 1-17.

Baldwin, Richard. 2012. "Sequencing Asian Regionalism: Theory and Lessons from Europe." Journal of Economic Integration 27 (1): 1-32.

Beeson, Mark. 2014. Reconfiguring East Asia: Regional Institutions and Organizations after the Crisis. London: Routledge.

Besley, Timothy, and Torsten Persson. 2009. "The Origins of State Capacity: Property Rights, Taxation, and Politics." American Economic Review 99 (4): 1218-44.

- 2011. Pillars of Prosperity: The Political Economics of Development Clusters. Princeton: Princeton University Press.

Bruszt, Laszlo, and Julia Langbein. 2015. "Development by Stealth: Governing Market Integration in the Eastern Peripheries of the European Union.” MAXCAP Working Paper Series 17. November.

Bruszt, Laszlo, and Ludvig Lundstedt. 2016. "Institutional Change During the EU Accession: Introducing a New Dataset Berlin.” MaxCap Working Paper Series 25.

Bruszt, Laszlo, and Gerald McDermott, eds. 2014. Leveling the Playing Field: Transnational Regulatory Integration and Development. Oxford University Press.

Dewatripont, Mathias, and Gérard Roland. 1992. "Economic Reform and Dynamic Political Constraints." Review of Economic Studies 59 (4): 703-30.

1995. "The Design of Reform Packages under Uncertainty." American Economic Review 85 (5): 1207-23.

Dincecco, Mark, and Gabriel Katz. 2016. "State Capacity and Long-Run Economic Performance." Economic Journal 126 (590): 189-218.

European Commission. 1997. Agenda 2000: Reinforcing the Pre-Accession Strategy, DOC/97/7. Brussels.

Evans, Peter. 1995. Embedded Autonomy: States and Industrial Transformation. Princeton: Princeton University Press. 
Evans, Peter, Dietrich Rueschemeyer, and Theda Skocpol. 1985. Bringing the State Back in. Cambridge: Cambridge University Press.

Geddes, Barbara. 1994. Politician's Dilemma: Building State Capacity in Latin America. Berkeley: University of California Press.

Hoekman Bernard. 2016. "Deep and Comprehensive Free Trade Agreements." EUI Working Papers, RSCAS 2016/29.

Manin, Bernard. 1994. "Checks, Balances and Boundaries: The Separation of Powers in the Constitutional Debate of 1787." In The Invention of the Modern Republic, edited by B. Fontana. Cambridge: Cambridge University Press.

Montesquieu. 1777. The Spirit of the Laws, vol. 1, trans. Thomas Nugent (London: J. Nourse, 1777)

Motta, Massimo. 2004. Competition Policy: Theory and Practice. Cambridge: Cambridge University Press.

Pierson, Paul. 2000. "Increasing Returns, Path Dependence, and the Study of Politics." American Political Science Review 94 (2): 251-67.

Plümper, Thomas, Vera Troeger, and Philip Manow. 2005. "Panel Data Analysis in Comparative Politics: Linking Method to Theory." European Journal of Political Research 44 (2): 327-54.

Savoia, Antonio, and Kunal Sen. 2015. "Measurement, Evolution, Determinants, and Consequences of State Capacity: A Review of Recent Research.” Journal of Economic Surveys 29 (3): 441-58.

Smith, Adam. 1776. An Inquiry into the Nature and Causes of the Wealth of Nations. Oxford: Oxford University Press.

Stasavage, David. 2002. "Credible Commitment in Early Modern Europe: North and Weingast Revisited." Journal of Law, Economics, and Organization 18 (1): 155-86.

Stinchcombe, Arthur. 1968. Constructing Social Theories. New York: Harcourt, Brace and World.

Tilly, Charles. 1984. Big Structures, Large Processes, Huge Comparisions. New York: Russe; Sage Foundations.

Vogel, David, and Robert A. Kagan. 2002. "National Regulations in a Global Economy." In Dynamics of Regulatory Change: How Globalization Affects National Regulatory Policies, edited by David Vogel and Robert Kagan. Oakland: University of California Press: University of California International, and Area Studies Digital Collection.

Weber, Max. 1968. Economy and Society, edited by Guenter Roth and Claus Wittich. New York: Bedminster Press.

Weiss, Linda. 1998. The Myth of the Powerless State. New York: Cornell University Press. 


\section{Deep Economic Integration and State Capacity: A Mechanism for Avoiding the Middle-Income Trap?}

Exiting the middle-income trap requires costly improvements in state capacity. Can deep economic integration increase state capacity and, if so, how? This paper provides a conceptual framework, new measurement, and evidence. Focusing on a panel of European Union membership candidate countries, this paper documents the large variation in the evolution of state capacities and empirically identify key links and implementation sequences. The main result is the centrality of an intricate relationship between bureaucratic independence and judiciary capacity. Change in these two is a precondition for increasing internal and external competitions, which are key factors for successfully escaping the middle-income trap.

\section{About the Asian Development Bank}

ADB's vision is an Asia and Pacific region free of poverty. Its mission is to help its developing member countries reduce poverty and improve the quality of life of their people. Despite the region's many successes, it remains home to a large share of the world's poor. ADB is committed to reducing poverty through inclusive economic growth, environmentally sustainable growth, and regional integration.

Based in Manila, ADB is owned by 67 members, including 48 from the region. Its main instruments for helping its developing member countries are policy dialogue, loans, equity investments, guarantees, grants, and technical assistance.

$\mathrm{ADB}$ 